Original Paper

\title{
Pelatihan Pendampingan Kelas Mika (Milenial Berkarakter) untuk Meningkatkan Kreativitas Siswa dalam Memanfaatkan Barang Bekas
}

\author{
Emilda Prasiska ${ }^{1 *}$, Herlina Apriani ${ }^{1}$, Antoni Pardede ${ }^{1}$
}

${ }^{1}$ Program Studi Pendidikan Kimia, Universitas Islam Kalimantan Muhammad Arsyad Al-Banjari, Banjarmasin, Indonesia.

DOI: $10.29303 /$ jpmpi.v3i2.442

Sitasi: Prasiska, E., Apriana, H., \& Pardele, A. (2020). Pelatihan Pendampingan Kelas Mika (Milenial Berkarakter) untuk Meningkatkan Kreativitas Siswa dalam Memanfaatkan Barang Bekas. Jurnal Pengabdian Magister Pendidikan IPA. 3(2). doi: http://doi.org/10.29303/jpmpi.v3i2.442

*Corresponding Author: Emilda Prasiska, Program Studi Pendidikan Kimia, Universitas Islam Kalimantan Muhammad Arsyad Al-Banjari, Banjarmasin, Indonesia; Email: emildaprasiska@gmail.com

\begin{abstract}
Abstrak: Rendahnya kepedulian masyarakat dalam kegiatan mengelola sampah di lingkungan sekitar merupakan salah satu bentuk kurangnya kesadaran manusia dalam menjaga lingkungan. Perlu dilakukan suatu gerakan yang dapat menumbuhkan kesadaran untuk lebih peduli terhadap lingkungan. Gerakan ini dapat dilakukan dengan cara menanamkan pendidikan karakter peduli lingkungan sedini mungkin kepada siswa. Pendidikan karakter peduli lingkungan yang ditanamkan kepada siswa diharapkan dapat memberikan dampak positif terhadap cara berpikir dan perilaku siswa dalam menjaga lingkungan sekitar. Memanfaatkan barang bekas merupakan salah satu cara dalam mengelola sampah. Pelaksana melakukan pengabdian kepada masyarakat di SDN Kebun Bunga 9 Banjarmasin untuk memberikan pelatihan pendampingan kelas mika (milenial berkarakter) untuk meningkatkan kreativitas siswa dalam memanfaatkan barang bekas. Data dikumpulkan dengan menggunakan metode observasi, ceramah, tanya jawab dan demonstrasi. Hasil kinerja siswa dalam membuat tempat pensil dari botol bekas rata-rata memiliki skor sebesar 3.4 dengan kategori baik. Selain menambah wawasan siswa tentang pendidikan karakter peduli lingkungan kegiatan ini juga memberikan bekal keterampilan kepada siswa untuk membuat produk kreatif dalam memanfaatkan barang bekas.
\end{abstract}

Kata Kunci: Kelas Mika; Milenial Berkarakter; Pendidikan Karakter; Peduli Lingkungan; Barang Bekas.

\section{Pendahuluan}

Kurangnya kesadaran manusia dalam menjaga lingkungan sekitar merupakan salah satu penyebab munculnya permasalahan lingkungan. Menurut SLHI (2018) kepedulian masyarakat terhadap lingkungan masih tergolong rendah, hal ini ditunjukkan bahwa hanya 1,2 persen rumah tangga yang melakukan kegiatan daur ulang. Untuk itu perlu menumbuhkan kepedulian terhadap lingkungan diberbagai kalangan.

Dalam menumbuhkan kepedulian lingkungan perlu dilakukan gerakan, salah 
satu gerakan yang dapat dilakukan dengan cara menanamkan pendidikan karakter kepada siswa melalui pengarahan dan pembinaan agar dapat membentuk siswa yang peduli kepada lingkungan. Pendidikan karakter mengajarkan kebiasaan cara berpikir dan berperilaku seseorang untuk menjadi individu yang lebih baik (Prasiska, 2018). Oleh karena itu dengan menanamkan pendidikan karakter kepada siswa diharapkan dapat memberikan dampak positif terhadap cara berpikir dan perilaku siswa.

Karakter peduli lingkungan merupakan tingkah laku siswa dalam mengindahkan dan memperhatikan lingkungan yang ada di sekitarnya dengan cara menjaga kebersihan lingkungan, mengkonservasi lingkungan dan mengelola sampah menjadi kerajinan (Wiharyati, 2016). Memanfaatkan barang bekas yang tidak terpakai lagi merupakan salah satu cara dalam mengelola sampah. Memanfaatkan barang bekas menjadi barang yang memiliki nilai seni maupun nilai ekonomis diharapkan dapat memberikan dampak positif terhadap keterampilan kreatif siswa.

Kreativitas merupakan suatu tuntutan pendidikan dan kehidupan yang sangat penting pada saat ini. Kreativitas akan menghasilkan berbagai inovasi dan perkembangan baru dalam suatu kehidupan. Individu dan organisasi yang kreatif akan selalu dibutuhkan oleh lingkungannya karena mereka dapat mampu memenuhi kebutuhan lingkungan yang terus berubah dan mampu bertahan dalam kompetisi global yang dinamis dan ketat (Zaenuddin, 2017). Berdasarkan hasil wawancara dengan salah satu guru di sekolah tersebut, untuk mendidik siswa menjadi insan yang kreatif perlu upaya yang lebih optimal, seperti sarana dan prasarana yang mendukung. Dana yang terbatas, serta kurangnya fasilitas belajar menjadi salah satu kendala dalam mengasah kreativitas siswa.

Mengasah kreativitas siswa dapat dilakukan sejak dini dan bisa menggunakan barang-barang yang tidak terpakai. Selain tidak memerlukan dana yang besar, dengan memanfaatkan barang bekas juga berguna untuk memberikan wawasan dan juga pengalaman langsung kepada siswa untuk dapat mengasah keterampilannya. Dengan mengenalkan kepada siswa bahwa barangbarang yang tidak terpakai ketika dimodifikasi dengan memberikan sentuhan seni dapat dimanfaatkan lagi menjadi barang yang bermanfaat dan bahkan bisa memiliki nilai ekonomis.

Sekolah Negeri Kebun Bunga 9 Banjarmasin terletak di jalan Citrawati Komp.setia Kawan Rt.17 No.111, Kebun Bunga, Kec. Banjarmasin Timur, Kota Banjarmasin. Salah satu misi dari SD Kebun Bunga 9 Banjarmasin adalah mendidik siswa agar menjadi insan berakhlak mulia, mandiri, inovatif, kreatif, dan kompetitif. Berkaitan dengan misi tersebut, pihak sekolah selalu berusaha untuk mengoptimalkan upaya dalam mendidik siswa. Salah satu program yang dapat dilakukan untuk mengoptimalkan upaya dalam mendidik siswa untuk mencapai misi tersebut adalah dengan mengadakan program pelatihan pendampingan kelas mika (milenial berkarakter) untuk meningkatkan kreativitas siswa dalam memanfaatkan barang bekas.

\section{Metode Pelaksanaan}

Pelaksanaan kegiatan pengabdian ini dilakukan dengan menggunakan metode ceramah, demostrasi, dan pelatihan. Persiapan, Pelaksanaan, dan Evaluasi. Adapun Kegiatan yang dilakukan dalam mencapai tujuan pengabdian adalah sebagai berikut:

\section{Persiapan}

Mengurus perizinan untuk melaksanakan kegiatan pengabdian, seperti menghubungi kepala sekolah SDN Kebun Bunga 9 Banjarmasin, dan wali kelas VI untuk menetapkan jumlah peserta dan jadwal pelaksanaan pengabdian.

2. Pelaksanaan Kegiatan

Pelaksanaan pengabdian pelatihan pendampingan kelas mika (milenial berkarakter) untuk meningkatkan kreativitas siswa dalam memanfaatkan barang bekas dilakukan dengan menggunakan metode 
ceramah, demonstrasi, dan tanya jawab yang dilaksanakan pada bulan Februari 2020.

\section{Evaluasi Kegiatan}

Evaluasi kegiatan dilakukan dengan cara observasi yakni mengamati secara langsung kinerja dan hasil produk yang telah dibuat oleh peserta. Penilaian ini dilakukan pada tahapan persiapan, pelaksanaan, dan evaluasi dalam pembuatan tempat pensil dengan mengacu pada indikator yang tercantum pada rubrik yang telah disiapkan. Selain dilakukan penilaian kinerja juga diberikan kuisioner sebelum dan sesudah pelatihan untuk mengukur pengetahuan dan motivasi siswa setelah dilakukan pelatihan.

\section{Hasil dan Pembahasan}

Dari hasil pengabdian masyarakat yang diikuti oleh 21 peserta pelatihan diperoleh dua hasil data, antara lain dari hasil observasi terhadap 3 kelompok kelas mika (milenial berkarakter) dan sebaran kuisioner yang diberikan sesudah dilakukan pelatihan. Adapun hasil observasi terhadap kinerja dan produk buatan siswa dapat dilihat pada tabel di bawah ini :

Tabel 1. Hasil Penilaian Kinerja dan Produk Siswa

\begin{tabular}{|c|c|c|c|c|c|c|}
\hline \multirow[t]{2}{*}{ No. } & \multirow[t]{2}{*}{ Keterampilan yang diamati } & \multicolumn{3}{|c|}{ Kelompok } & \multirow[t]{2}{*}{$\sum$ Skor } & \multirow[t]{2}{*}{ Kategori } \\
\hline & & 1 & 2 & 3 & & \\
\hline 1. & $\begin{array}{l}\text { Persiapan (pemilihan bahan, pengukuran, } \\
\text { persiapan alat) }\end{array}$ & 3 & 3 & 3 & 3 & Baik \\
\hline 2. & Penggunaan peralatan yang benar & 4 & 3 & 3 & 3.3 & Baik \\
\hline 3. & Ketepatan langkah pembuatan & 3 & 4 & 4 & 3.6 & Baik \\
\hline 4. & Kesesuian hasil akhir & 4 & 4 & 4 & 4 & Sangat baik \\
\hline 5. & Kreatifitas produk & 4 & 4 & 3 & 3.6 & Baik \\
\hline 6. & Kerapian Produk & 3 & 4 & 3 & 3.3 & Baik \\
\hline 7. & $\begin{array}{l}\text { Menata peralatan setelah selesai melakukan } \\
\text { kegiatan }\end{array}$ & 4 & 4 & 3 & 3.6 & Baik \\
\hline 8. & $\begin{array}{l}\text { Menjaga kebersihan lingkungan kelas setelah } \\
\text { selesai kegiatan. }\end{array}$ & 3 & 4 & 3 & 3.3 & Baik \\
\hline \multicolumn{2}{|c|}{$\sum$ Total Skor } & & & & 3.4 & Baik \\
\hline
\end{tabular}

Sumber : Hasil Pengolahan Data

Keterangan : 4= Sangat Baik, 3 = Baik, 2 = Cukup, 1 = Kurang (Ulya, 2017)

Berdasakan tabel 1 hasil penilaian kinerja dan produk siswa pada keterampilan yang diamati untuk tahapan ke-1 yaitu persiapan siswa dalam kategori baik, hal ini disebabkan karena sebelum melakukan kegiatan pelatihan tim pelaksana melakukan pengarahan kepada siswa untuk mempersiapkan atau membawa alat dan bahan yang mereka punya seperti botol bekas, gunting atau cuter. Pada tahapan ke-2 yakni penggunaan peralatan juga dalam kategori baik. Hal ini ditunjukkan dengan ketepatan siswa dalam mengukur dan memotong pola pada kain flannel yang telah disediakan, juga dilihat dari ketepatan siswa dalam menggunakan jangka untuk membuat pola lingkaran pada kain flannel. Tahapan ke-3 yaitu ketepatan langkah pembuatan produk berkategori baik hal ini disebabkan rata-rata siswa membuat tempat pensil dari botol secara berurutan sesuai dengan langkah kerja pada lembar kerja siswa. Pada tahapan ke-4 yakni kesesuaian hasil akhir terhadap produk yang telah di demostrasikan berkategori sangat baik, karena semua kelompok menghasilkan produk berupa tempat pensil dari botol bekas seperti yang telah di demonstrasikan oleh tim pelaksana. Tahapan selanjutnya yaitu tahapan ke-5 kreatifitas produk berkategori baik, hal ini ditunjukkan hasil produk yang dibuat oleh kelompok 1, 2, dan 3 terdapat modifikasi yang dilakukan siswa terhadap tempat pensil yang mereka buat. 


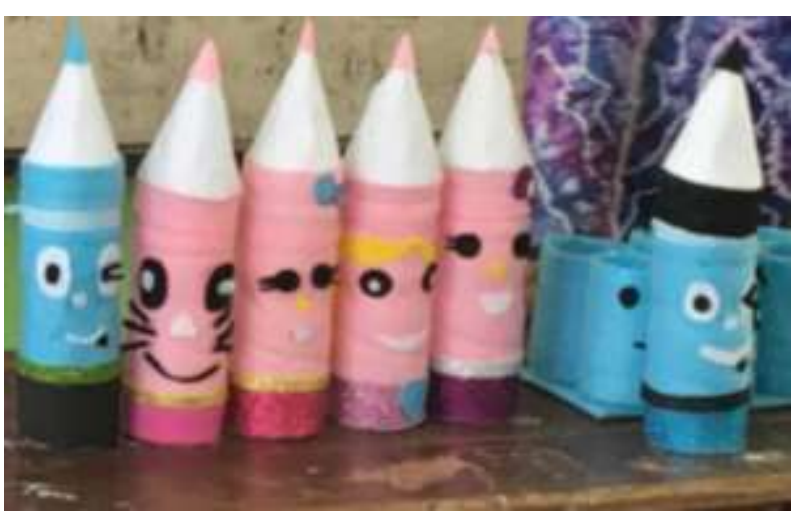

Sumber : Foto Dokumentasi Pribadi

Gambar 1 Tempat Pensil dari Botol Bekas Karya Kelompok 1, 2, dan 3

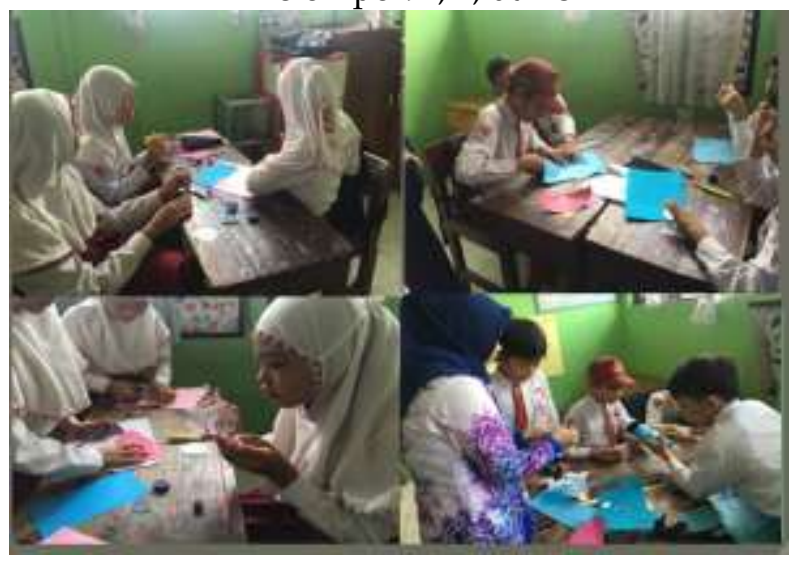

Sumber : Foto Dokumentasi Pribadi

Gambar 2 Siswa membuat tempat pensil dari botol bekas

Berdasarkan gambar diatas terdapat modifikasi hasil produk tempat pensil yang dibuat oleh kelompok 1, 2, dan 3. Hal ini dapat dilihat dari pemilihan warna pada bagian bawah tempat pensil dan bentuk karakter yang dibuat oleh siswa berbeda dengan tempat pensil buatan tim pelaksana.

Tahapan selanjutnya yakni tahapan ke -6 kerapian produk berkategori baik, hal ini dilihat dari kerapian siswa dalam membuat tempat pensil, baik ketika memberi lem/ perekat pada kain flannel maupun pada saat memotong pola pada kain flannel, walaupun ada kelompok yang sedikit kurang rapi tapi rata-rata masih berkategori baik. Selanjutnya tahapan ke-7 yaitu menata peralatan setelah selesai melakukan kegiatan berkategori baik, hal ini ditunjukkan ketika selesai kegiatan siswa merapikan dan meletakkan peralatan yang telah digunakan ke tempat yang telah disediakan. Dan tahapan terakhir yaitu tahapan ke-8 menjaga kebersihan lingkungan kelas setelah selesai kegiatan juga berkategori baik. Hal ini ditunjukan ketika siswa selesai kegiatan tanpa diminta rata-rata siswa membersihkan sampah yang berserakan bekas sisa kain flannel atau kertas yang telah mereka gunakan sebelumnya.

Data hasil kuisioner yang diberikan kepada 21 peserta pelatihan pendampingan kelas mika (milenial berkarakter) untuk meningkatkan kreativitas siswa dalam memanfaatkan barang bekas dapat dilihat pada tabel di bawah ini :

\section{Tabel 2. Hasil Kuisioner}

\begin{tabular}{llll}
\hline No. & Aspek yang dinilai & $\begin{array}{l}\text { Persentase } \\
\text { Pretest }\end{array}$ & Postest \\
\hline 1. & Pengetahuan & $15.8 \%$ & $96.8 \%$ \\
2. & Motivasi Siswa & $22.6 \%$ & $90.5 \%$ \\
\hline
\end{tabular}

Berdasarkan Tabel 2. Hasil kuisioner yang diberikan kepada siswa sebelum dan sesudah dilakukan pelatihan, dapat disimpulkan bahwa terjadi peningkatan dalam aspek pengetahuan dan motivasi siswa dalam memanfaatkan barang bekas. Pada aspek pengetahuan terjadi peningkatan sebesar $81 \%$, sedangkan untuk aspek motivasi siswa dalam memanfaatkan barang bekas terjadi peningkatan sebesar $67.9 \%$. Hal ini ditunjukkan dengan adanya respon positif dari siswa pada kuisioner yang diberikan setelah pelatihan dilaksanakan. Hasil dari pertanyaan pada aspek pengetahuan menunjukkan bahwa dengan adanya pelatihan ini dapat memberikan tambahan pengetahuan dan wawasan kepada peserta pelatihan tentang pendidikan karakter yakni peduli lingkungan.

Para peserta menunjukkan perhatian yang tinggi terhadap ceramah yang disampaikan oleh tim pelaksana, dan para peserta menunjukkan reaksi positif terhadap ketertarikan dalam membuat tempat pensil dari botol bekas. Hal ini juga ditunjukkan dari respon siswa pada pertanyaan yang terdapat pada aspek motivasi siswa dalam mengikuti pelatihan. Dengan demikian kegiatan ini 
memiliki dampak positif untuk meningkatkan motivasi dan kreativitas siswa dalam memanfaatkan barang bekas menjadi barang yang lebih bermanfaat bahkan memiliki nilai ekonomis.

\section{Kesimpulan}

Dari hasil kegiatan pelatihan pendampingan kelas mika (milenial berkarakter) untuk meningkatkan kreativitas siswa dalam memanfaatkan barang bekas, maka dapat disimpulkan bahwa: 1) Kegiatan ini memberikan tambahan wawasan pengetahuan dan pemahaman mengenai pendidikan karakter peduli lingkungan. 2) Kegiatan ini juga memberikan bekal keterampilan kepada siswa untuk membuat produk kreatif dalam memanfaatkan barang bekas seperti botol plastik bekas yang dapat dimanfaatkan menjadi tempat pensil.

\section{Ucapan Terimakasih}

Terima kasih kepada Universitas Islam Kalimantan Muhammad Arsyad Al-Banjari Banjarmasin yang telah mendukung secara moral maupun material, dan pihak-pihak terkait yang senantiasa selalu memberikan dukungan dalam terlaksananya kegiatan pengabdian kepada masyarakat ini.

\section{Daftar Pustaka}

Prasiska, E. (2018). Upaya Guru Dalam Menanamkan Pendidikan Karakter Pada Pembelajaran Biologi Di Sma Muhammadiyah 1 Banjarmasin. Prosiding Hasil-Hasil Penelitian Tahun 2018 ISBN: 978-602-52531-1-9 Dosen-Dosen Universitas Islam Kalimantan, Mei 2018. http:/ / ppj.uniska-bjm.ac.id/wpcontent/uploads/2018/09/4-FKIP-128177-6.pdf Diakses pada tanggal 19 September 2019.

Statistik Lingkungan Hidup Indonesia, (2018). Pengelolaan Sampah di Indonesia. Badan Pusat Statistik : Jakarta.
Ulya, E.D. (2017). Pelatihan Pemanfaatan Barang Bekas Sebagai Bahan Pembuatan Reusable Bag Untuk Melatih Siswa Madrasah Ibtidaiyah Dalam Melakukan Diet Plastik. Prosiding Seminar Nasional dan Internasional. UNIMUS; Semarang. https://jurnal.unimus.ac.id/index.php/ psn12012010/article/view/2346/2320

Diakses pada tanggal 19 September 2019.

Wiharyanti, D. (2016). Pembinaan Karakter Peduli Lingkungan Melalui Pengelolaan Sampah Anorganik Menjadi Kerajinan Di Gugus Depan 03.061-03.062 Smp Negeri 13 Semarang. Fakultas Ilmu Sosial Universitas Negeri Semarang. Semarang. https://lib.unnes.ac.id/27496/1/3301412 031.pdf Diakses pada tanggal 20 September 2019

Zaenuddin, A. (2017). Pengembangan Kreativitas Peserta Didik Dalam Pembelajaran Tematik Terpadu Kelas IV MIN Bener Purworejo.Fakultas Ilmu Tarbiah dan Keguruan UIN Sunan Kalijaga. Yogyakarta. $\quad$ http://digilib.uinsuka.ac.id/29384/1/1520421002_BABI_IV-atau-V_DAFTAR-PUSTAKA.pdf Diakses pada 20 September 2019. 